\title{
An Outbreak of Mucosal Disease in a Dairy Herd
}

\author{
By T. Løken, H. Gamlem and O. Lysbakken \\ National Veterinary Institute, Oslo, Norway.
}

\begin{abstract}
Løken, T., H. Gamlem and O. Lysbakken: An outbreak of mucosal disease in a dairy herd. Acta vet. scand. 1989, 30, 321-327. - An outbreak of mucosal disease (MD) was studied in a dairy herd, comprising 12 cows, 9 heifers and 18 calves. During a period of 1 month, six 5 to 8 month-old calves showed typical signs of MD. They all died or were killed in extremis after 2-8 days with progressively worsening clinical signs. Post mortem lesions were examined in one calf. Non-cytopathogenic MD virus was isolated from serum or tissues from 3 clinically affected calves and from 1 healthy heifer. All cows and heifers except for the viremic one possessed neutralizing antibodies against bovine pestivirus. According to the current MD-pathogenesis concept, the affected calves were probably infected transplacentally during the first half of foetal life with pestivirus from the persistently infected heifer in the herd.
\end{abstract}

cattle; mucosal disease; pestivirus; persistent infection; BVD/MD virus; neutralizing antibodies.

\section{Introduction}

Mucosal disease (MD) is a syndrome in cattle caused by infection with pestivirus. Dissimilar conditions such as bovine virus diarrhoea (BVD), different manifestations of reproductive failure and congenital disorders in progeny, are all caused by the same virus. MD was first described by Ramsey \& Chivers in 1953, and BVD in 1946 by Olafson et al. The BVD/MD virus was first isolated and reported by Baker et al. (1954). In sheep and goats, a closely related pestivirus is the cause of border disease (BD) (Acland et al. 1972), which may also be induced by bovine strains of the virus (Ward 1971).

MD occurs in young cattle, mostly at 4-24 months of age. Most likely, they are all persistently infected with non-cytopathogenic pestivirus acquired in utero (Roeder 1982, Harkness et al. 1984). Brownlie et al. (1987) suggested that MD is induced in such animals by superinfection with a cytopathogenic strain. Though infected cattle may be cli- nically normal, many show illthrift and reduced growth rate in calfhood (Duffell \& Harkness 1985).

According to Saxegaard et al. (1971) MD has been diagnosed for more than 20 years in Norway. BVD/MD virus has been isolated occasionally since 1967 , also in outbreaks involving several animals (Krogsrud, personal information). A case of atypical MD was reported by Saxegaard et al. in 1971. However, detailed investigations in herds with several cases of MD have not been reported. The present paper describes an outbreak of typical MD in a dairy herd in Norway, and the epidemiological features are discussed.

\section{Materials and methods}

The herd

The affected herd comprised 12 dairy cows, 9 heifers and 18 calves 3 to 9 months old, all Norwegian Red Cattle. The herd was housed during the winter until June. The cows, heifers and the oldest calves were tied up in 
rows and fed silage, hay and mixed concentrates. The youngest calves were kept in pens on slatted floors, and received colostrum or reconstituted milk. During the summer, the animals were turned out onto grass where they were kept in common with cattle from several farms in the local district. There were no animals introduced into the herd during the 2 year period preceding the outbreak. The animals had never been vaccinated against BVD/MD virus.

The cows and heifers were all bred in December-January by artificial insemination. Contrary to the normal situation in this herd, about half of the animals inseminated returned to service at irregular intervals during a period of a few months from January 1985 and onwards. Prior to this, some of the cows in question had been found pregnant by rectal examination. No signs of abortion were seen.

One 6 month-old calf died during the outbreak without any signs or lesions, and attempts to isolate MD virus were unsuccessful. This calf was probably accidently strangled to death by its tying chain and is consequently excluded from this study.

\section{Clinical examination}

During the course of the outbreak, the animals were clinically examined in a routine manner.

\section{Laboratory procedures}

Pathological examinations were performed in 1 calf necropsied in the field, from which selected viscera were submitted to the laboratory. Tissues for light microscopy were fixed in phosphate-buffered formalin, processed routinely and stained with hematoxylin eosin (HE).

Bacteriological examinations of liver and intestinal contents from the necropsied calf included examinations for Salmonella spp. (Cottral 1978). Faeces from 2 other calves was similarly tested.

Virological examinations included inoculation of serum or homogenized tissues in Earle's solution onto calf kidney (CK) cell cultures, which were incubated at $37^{\circ} \mathrm{C}$ for 7 days. Cultures were examined for non-cytopathogenic BVD/MD virus by an immunoperoxidase technique (Meyling 1983).

Examination for neutralizing serum antibodies against the NADL strain of BVD/MD virus was carried out as described by Løken et al. (1982). The neutralization titres are expressed as the reciprocal of the highest of the four-fold serum dilutions that prevented cytopathogenic effect in at least 1 of the 2 replicate cultures.

\section{Results}

\section{Clinical findings}

Signs were initially observed in May 1986 in 1 calf (no. 1 in Table 1), which died 2 days later. During the outbreak, a total of 6 calves at ages ranging from 5-8 months showed similar signs, which were characterized by anorexia, diarrhoea, dehydration, pyrexia and general depression. The highest recorded rectal temperature was $40.5^{\circ} \mathrm{C}$. Three of the calves showed nasal discharge and mucosal erosions in the gingiva and the palate. Oxytetracycline given parenterally had no apparent effect. All 6 cases died or were killed in extremis within 2-8 days of the onset of signs. They all died within a period of 1 month (Table 1).

The cows and heifers showed no signs, and they were all in good condition during the outbreak (Table 1). Even the heifer which was demonstrated persistently infected with BVD/MD virus was clinically normal until slaughtered 6 months later. This animal, however, was fairly small for its age due to poor growth rate during the first year of life. 
Table 1. Virological and serological examinations of a herd outbreak of mucosal disease (MD). The relationship between the birth date of a persistently infected heifer and the conception time of the calves is shown.

\begin{tabular}{cclll}
\hline Animals & $\begin{array}{l}\text { Time of conception } \\
\pm \text { days* }\end{array}$ & $\begin{array}{l}\text { MD virus isolation } \\
\text { (serum or tissue) }\end{array}$ & $\begin{array}{l}\text { Neutralizing } \\
\text { antibody titre }\end{array}$ & $\begin{array}{l}\text { Health condition } \\
\text { during } 1986\end{array}$ \\
\hline 12 cows & & n.e. & $64-1024$ & $\begin{array}{l}\text { No signs } \\
\text { heifers }\end{array}$ \\
$\begin{array}{l}1 \text { heifer } \\
18 \text { calves: }\end{array}$ & Born 03.01 .85 & - & $64-1024$ & No signs \\
no. 1 & -10 & + (persistent viremia) & $<4$ & $\mathrm{~S}, 05.12$ \\
no. 2 & -22 & n.e. & n.e. & D, 19.05 (initial case) \\
no. 3 & -22 & + & n.e. & D, 02.06 \\
no. 4 & -11 & + & $<4$ & $\mathrm{~K}, 13.06$ \\
no. 5 & +9 & + & $<4$ & $\mathrm{~K}, 13.06$ \\
no. 6 & +112 & - & 64 & $\mathrm{~K}, 13.06$ \\
no. 7 & +67 & - & 16 & $\mathrm{~K}, 13.06$ \\
no. $8-17$ & $+6-+150$ & - & 256 & $\mathrm{~S}, 14.06$ \\
\hline
\end{tabular}

*Days prior to (-) or after (+) birth of the persistently infected heifer

n.e. $=$ not examined

$\mathrm{D}=$ died

$\mathrm{K}=$ killed in extremis

$\mathrm{S} \quad=$ slaughtered (healthy)

\section{Laboratory findings}

Pathological findings: Gross lesions were evident in the intestine of the examined calf. The mucosa of the small intestine was severely hyperaemic, with finbrino-hemorrhagic exudate and diphtheric membranes overlying and outlining Peyer's patches. A non-specific catarrhal typhlocolitis without mucosal ulceration was found. Histopathological changes in the jejuno-ileal mucosa consisted of epithelial necroses in the Lieberkuhn's crypts and dilated crypts filled with mucus, epithelial debris and leukocytes. Severe mucosal inflammation was seen over Peyer's patches, accompanied by collapse of the lamina propria, lysis of the follicular lymphoid tissues and herniation of the dilated crypts into the submucosa replacing necrotic Peyer's patches. A mild mononuclear inflammatory cell reaction in arterial walls and in perivascular areas was present in the submucosa.
The brain was macroscopically normal. Histopathological examination revealed a mild to moderate vasculitis and perivasculitis with multifocal infiltrations of mononuclear cells in the leptomeninges and the cerebral cortex.

Bacteriological findings: No pathogenic bacteria were recovered from any animal. Virological findings: Cytopathogenic virus was not demonstrated. Non-cytopathogenic BVD/MD virus, however, was isolated from serum from 1 healthy heifer and from serum or tissues from 3 affected calves, as shown in Table 1. However, serum from 2 affected calves (nos. 5 and 6) was virus negative. Serum sampled from the infected heifer 4 weeks and 4 months later was still virus positive.

Serological findings: All 12 cows and all but 1 of the 9 heifers were found to be positive for neutralizing serum antibodies against the BVD/MD virus (Table 1). Antibody 
titres were 64,256 , and 1024 in 9, 9, and 2 of these animals, respectively. The antibody negative heifer (titre $<4$ ) was the one found to be viremic. Three of 5 examined calves (nos. 5-7) had antibody titres ranging from 16 to 256 . Antibodies were not demonstrated in serum from 2 affected calves (nos. 3 and 4) from which virus was isolated.

\section{Discussion}

The clinical signs observed in the calves and the post mortem lesions demonstrated in one of them, strongly indicated MD. The findings were in good accordance with other reports on the syndrome (Ramsey \& Chivers 1953, French \& Snowdon 1964, Barker \& van Dreumel 1985, Brownlie 1985). The diagnosis of MD was verified by the isolation of BVD/MD virus from 3 calves showing characteristic lesions.

All 27 animals virologically or serologically examined were found to have been infected with pestivirus. The demonstration of serum antibodies in all virus negative animals examined in the herd, is in agreement with established criteria concerning a confirmed diagnosis of MD (Roeder 1982, Brownlie 1985). The high antibody titres found in the present herd do not give any indication about the time of introduction of the infection. Neutralizing antibodies have been shown to decrease slowly, often over a period of years (Kahrs et al. 1966).

Introduction of cattle persistently infected with pestivirus into susceptible herds is most hazardous because such animals are efficient virus transmitters, and probably it is a common mode of natural spread of virus (Malmquist 1968, Duffell \& Harkness 1985). In the present herd, the birth of the persistently infected heifer in January 1985 had probably a similar transmitting effect. This animal was most likely a continuous and efficient virus reservoir to susceptible cattle in the herd.
The calves which succumbed in the MD outbreak, must have been infected in utero within about 120 days after conception (Roeder 1982, Roeder \& Drew 1984, Brownlie et al. 1984). These were all conceived between the middle of December 1984 and late April 1985. So, the first weeks of life of the persistently infected heifer coincided with the hazardous period when most of the susceptible cows were in early pregnancy. Some 18 months later in the spring of 1986,6 persistently infected calves developed MD, a disease which Roeder \& Drew (1984) characterized as a late sequel to foetal infection. Other infected foetuses probably died and were absorbed or expelled undetected; the now immunized cows returning to service and subsequently undergoing a normal pregnancy. This is in accordance with studies by Zemjanis \& Hurtgen (1975) and Whitmore et al. (1981). Outbreaks of early foetal death are also a facet of the BVD/MD syndrome (Brownlie 1985, Roeder et al. 1986, McClurkin et al. 1979).

The dam of the infected heifer was slaughtered prior to the present examinations. This cow was obviously no efficient excreter of pestivirus, since most of the herd were still susceptible to the virus at the breeding season of $1984 / 85$. On this basis, the former cow was most likely not persistently infected but had been acutely infected in early pregnancy, which means during the grazing season of the spring/summer of 1984. This horizontal infection was probably due to incidental contact with an unknown, persistently infected calf on the pasture, on which the herd was kept in common with cattle from other farms.

Two affected calves were found to be virus negative and antibody positive. These are rather confusing findings, which may have different explanations. In the $41 / 2$ month-old calf (no. 6), the titre of 16 may be ascribed to 
maternally derived antibodies (Frey et al. 1987). The 8 month-old calf (no. 5) had probably developed active immunity, however, the antibody titre of 64 is about at the upper limit of the antibody titre range reported in persistently infected calves (Duffell \& Harkness 1985). In both these animals the serum antibodies probably interfered with virus isolation and might thus have caused a false negative result. On the other hand, these calves might have seroconverted due to the assumed superinfection with a BVD/MD virus which induced the MD (Gardiner et al. 1983, Brownlie et al. 1984).

In the present study, only non-cytopathogenic pestivirus was isolated, also from spleen which are commonly used for the isolation of cytopathogenic strains (Barber et al. 1985, McClurkin et al. 1985). At our laboratory, however, cytopathogenic virus are only occasionally isolated from viscera in field cases of MD. These findings are contrary to most reports on virus isolations in MD (Gillespie et al. 1960, McClurkin et al. 1985). This disagreement may be due to differences in extrinsic factors such as the type of culture cells, the host tissue examined, and, particularly, the biotype of different field viruses (Littlejohns \& Walker 1985, Fernelius et al. 1969, McClurkin et al. 1985).

In conclusion, this outbreak of MD was most likely due to an initial, horizontally transmitted pestivirus infection in early pregnancy in 1 susceptible cow 2 years previously, with persistent infection of the foetus as a consequence. This infected progeny, born $1 \frac{1}{2}$ year before the outbreak, most likely transmitted the virus to the rest of susceptible animals in the herd. These findings demonstrated one mode of introduction and spread of pestivirus in a susceptible herd of cattle. Most outbreaks of MD in Norwegian herds examined during the last few years, seem to have included a similar mode of vi- rus transmission. That is in accordance with other reports on the disease (Cranwell \& Drew 1984, Harkness et al. 1984).

\section{Acknowledgements}

We are indebted to Dr. H. Stenwig, National Veterinary Institute, Oslo, for bacteriological examinations, and to the herd owner for all his assistance and detailed registrations.

\section{References}

Acland HM, Gard GP, Plant JW: Infection of sheep with mucosal disease virus. Aust. vet. J. 1972, 48, 70.

Baker JA, York CJ, Gillespie JH, Mitchell GB: Virus diarrhea in cattle. Amer. J. vet. Res. 1954, 15, 525-531.

Barber DML, Nettleton PF, Herring JA: Disease in a dairy herd associated with the introduction and spread of bovine virus diarrhoea virus. Vet. Rec. 1985, 117, 459-464.

Barker IA, van Dreumel AA: The alimentary system. In: K. V. F. Jubb, P. C. Kennedy \& N. Palmer (eds.): Pathology of Domestic Animals. Academic press, Inc., 3.ed. 1985, vol. 2, pp. 95-100.

Brownlie J: Clinical aspects of the bovine virus diarrhoea/mucosal disease complex in cattle. In Practice 1985, 7, 195-202.

Brownlie J, Clarke MC, Howard CJ: Experimental production of fatal mucosal disease in cattle. Vet. Rec. 1984, 114, 535-536.

Brownlie J, Clarke MC, Howard CJ: Clinical and experimental mucusal disease - defining a hypothesis for pathogenesis. In: J. W. Harkness (ed.): Agriculture. Pestivirus infections of ruminants. Luxembourg, Office for Official Publications of the European Communities 1987, p. 147-156.

Cottral GE (ed.): Manual of Standardized Methods of Veterinary Microbiology. Comstock Publishing Associates, Cornell Univ. Press, Ithaca and London 1978, p. 360.

Cranwell MP, Drew TW: Mucosal disease in cattle. Vet. Rec. 1984, 114, 229.

Duffell SJ, Harkness JW: Bovine virus diarrhoeamucosal disease infection in cattle. Vet. Rec. 1985, 117, 240-245.

Fernelius AL, Lambert G, Hemness GJ: Bovine viral diarrhea virus-host cell interactions: Adaptation 
and growth of virus in cell lines. Amer. J. vet. Res. 1969, 30, 1561-1572.

French EL, Snowdon WA: Mucosal disease in Australian cattle. Aust. vet. J. 1964, 40, 99-105.

Frey HR, Liess B, Peters W, Roming L, Lehmann B: Account of the etiological relation of BVD virus infections in cattle to clinically suspect cases of bovine viral diarrhoea. In: J. W. Harkness (ed.): Agriculture. Pestivirus infections of ruminants. Luxembourg, Office for Official Publications of the European Communities 1987, p. 123-130.

Gardiner AC, Nettleton PF, Barlow RM: Virology and immunology of a spontaneous and experimental mucosal disease-like syndrome in sheep recovered from clinical border disease. J. comp. Path. 1983, 93, 463-469.

Gillespie JH, Baker JA, McEntee K: A cytopathogenic strain of virus diarrhea virus. Cornell Vet. 1960, 50, 73-79.

Harkness JW, Roeder PL, Wood L: Mucosal disease in cattle. Vet. Rec. 1984, 114, 186.

Kahrs RF, Robson DS, Baker JA: Epidemiological considerations for the control of bovine virus diarrhea. Proc. 70th Ann. Meet, U.S., Livestock San. Ass., New York 1966, p. 145-153.

Littlejohns IR, Walker $K H$ : Aetiology and pathogenesis of mucosal disease of cattle: Current concepts, observations and speculation. Aust. vet. J. 1985, 62, 101-103.

Loken $T$, Hyllseth B, Larsen HJ: Border disease in Norway. Serological examination of affected sheep flocks. Acta vet. scand. 1982, 23, 46-52.

Malmquist WA: Bovine viral diarrhea - mucosal disease: Etiology, pathogenesis, and applied immunity. J. Amer. vet. med. Assoc. 1968, 152, 763768.

McClurkin AW, Bolin SR, Coria MF: Isolation of cytopathic and noncytopathic bovine viral diarrhea virus from the spleen of cattle acutely and chronically affected with bovine viral diarrhea. J. Amer. vet. med. Assoc. 1985, 186, 568-569.

McClurkin AW, Coria MF, Cutlip RC: Reproductive performance of apparently healthy cattle persistently infected with bovine viral diarrhea virus. J. Amer. vet. med. Assoc. 1979, 174, 11161119.
Meyling A: An immunoperoxidase (PO) technique for detection of BVD virus in serum of clinically and subclinically infected cattle. Proc. 3rd. Int. Symp. of Vet. Lab. Diagn., Ames 1983, p. 179184.

Olafson P, MacCallum AD, Fox FH: An apparently new transmissible disease of cattle. Cornell Vet. 1946, 36, 205-213.

Ramsey FK, Chivers $\mathrm{WH}$ : Mucosal disease of cattle. N. Amer. Vet. 1953, 34, 629-633.

Roeder PL: Bovine mucosal disease - a persistent viral infection. Proc. 7th. Int. Symp. of the World Ass. of Vet. Micr., Imm. and Spec. in Inf. Diseases (W.A.V.M.). Barcelona 1982.

Roeder PL, Drew TW: Mucosal disease of cattle: A late sequel to fetal infection. Vet. Rec. 1984, 114, 309-313.

Roeder PL, Jeffrey M, Cranwell MP: Pestivirus fetopathogenicity in cattle: Changing sequelae with fetal maturation. Vet. Rec. 1986, 118, 44-48.

Saxegaard F, Bratberg B, Ek N: Isolation and identification of bovine viral diarrhea/mucosal disease virus (BVD/MD virus) from an atypical case resembling malignant catarrhal fever (MCF). Acta vet. scand. 1971, 12, 601-693.

Ward GM: Experimental infection of pregnant sheep with bovine viral diarrhoea - mucosal disease virus. Cornell Vet. 1971, 61, 179-191.

Whitmore HL, Zemjanis R, Olson J: Effect of bovine viral diarrhea virus on conception in cattle. $J$. Amer. vet. med. Assoc. 1981, 178, 1065-1067.

Zemjanis R, Hurtgen JP: Early prenatal deaths in cattle caused by BVD-MD virus. Sum. 20th. World Vet. Congr., Thessaloniki 1975, vol. 2, p. 853.

\section{Samandrag}

Eit utbrot av mucosal disease i ein buskap av mjølkekyr.

Eit utbrot av mucosal disease (MD) vart undersøkt i ein buskap av Norsk Rødt Fe som omfatta 12 mjølkekyr, 9 kviger og 18 kalvar. I eit tidsrom av 1 månad viste 6 kalvar typiske teikn på MD. Alle desse kalvane døydde eller vart avliva i moribund tilstand etter ein 2-8 dagars periode med forverrande sjukdom. 
Noncytopatogent MD virus vart isolert frå serum eller vev frå 3 sjuke kalvar og 1 frisk kvige. Alle kyrne og kvigene utanom den eine som vart funne viremisk, hadde nøytraliserande antistoff $i$ serum mot bovint pestivirus. I samsvar med patogenesen ved MD vart dei affiserte kalvane truleg infiserte transplacentalt i første halvdel av fosterlivet med pestivirus frå den persistent infiserte kviga i buskapen.

(Received August 25, 1988; accepted November 14, 1988).

Reprints may be requested from: Torleiv Løken, National Veterinary Institute, P. O. Box 8156 Oslo Dep., N0033 Oslo 1, Norway. 
